\title{
PARTISIPASI GURU DALAM PENETAPAN RENCANA KEGIATAN DAN ANGGARAN DI MADRASAH IBTIDAIYAH SWASTA
}

\section{TEACHER PARTICIPATION IN DETERMINING ACTIVITY PLAN AND BUDGET IN PRIVATE IBTIDAIYAH MADRASAH}

\author{
Nurhattati ${ }^{1}$, Ahmad Jauhari Hamid Ripki ${ }^{2}$ \\ ${ }^{1}$ Universitas Negeri Jakarta, \\ ${ }^{2}$ STKIP Kusumanegara \\ email: nurhattati@unj.ac.id
}

Naskah Diterima: 20 Mei 2021; Direvisi: 25 Juni 2020; Disetujui: 23 November 2021

\begin{abstract}
The lack of teacher participation in the preparation of the RKAM has an impact on the disbursement of BOS funds of Private Madrasah Ibitdaiyyah in Karawang Regency. The initial assumption is the teacher's lack of knowledge regarding the RKAM, the level of participation in determining the RKAM and the factors that influence it. The study used a survey method of data collection techniques in the form of a questionnaire in the form of an attitude scales/scaled distributed among/over 301 respondents, strengthened by documentation studies and FGDs with key informants and informants. The results showed (1) teachers ' understanding of RKAM both in the aspect of activity planning, budgeting and operation of the e-RKAM system was very low; (2)Teacher participation in determining the RKAM both in determining the vision, mission, values, goals, targets is low; (3) The lack of socialization of the RKAM, the limited opportunities given to teachers to participate, in addition, the internal factors of teachers related to age, tenure and employee status and limitations in operating the e-budget have an impact on the low participation of teachers in determining the RKAM. For this reason, it is recommended that madrasas should socialize and provide opportunities for teachers to participate in RKAM, and the government will create a teacher participation system in RKAM.
\end{abstract}

Keywords: School Based Management (SBM); Teacher Participation and Activity Plan and Budget

\begin{abstract}
Abstrak
Minimnya partisipasi guru dalam penyusunan RKAM berdampak pada pencairan dana BOS di Madrasah Ibitdaiyyah Swasta di Kabupaten Karawang. Asumsi awal adalah kurangnya pengetahuan guru terkait RKAM, tingkat partisipasi dalam penetapan RKAM dan faktor-faktor yang mempengaruhinya. Penelitian menggunakan metode survei dengan teknik pengumpulan data berupa angket dalam bentuk skala sikap yang disebar terhadap 301 responden, diperkuat dengan studi dokumentasi dan FGD dengan informan dan narasumber kunci. Hasil penelitian menunjukkan (1) Pemahaman guru terhadap RKAM baik pada aspek rencana kegiatan, penganggaran dan pengoperasian sistem e-RKAM sangat rendah; (2) Partisipasi guru dalam penetapan RKAM baik dalam penetapan visi, misi, nilai, tujuan, sasaran rendah. (3) Kurangnya sosialisasi RKAM, terbatasnya kesempatan yang diberikan pada guru untuk berpartisipasi, selain, faktor internal guru terkait usia, masa kerja dan status pegawai dan keterbatasan dalam pengoperasian e-anggaran berdampak terhadap rendahnya partisipasi guru dalam penetapan RKAM. Untuk itu direkomendasikan madrasah hendaknya mensosialisasikan dan memberi kesempatan guru untuk berpartisipasi dalam RKAM, dan pemerintah membuat sistem partisipasi guru dalam RKAM.
\end{abstract}

Kata kunci: Manajemen Berbasis Sekolah (MBS); Partisipasi Guru dan Rencana Kegiatan dan Anggaran 


\section{PENDAHULUAN}

Salah satu produk desentralisasi pendidikan di Indonesia sejak pemberlakuan UU No. 22 Tahun 1999, UU No. 25 Tahun 1999, UU No. 20 Tahun 2003 yang dikuatkan dengan PP No. 19 tahun 2005, adalah diterapkannya pola penyelenggaraan pendidikan berdasarkan Manajemen Berbasis Sekolah (MBS). MBS pada hakikatnya merupakan bentuk desentralisasi yang memosisikan sekolah sebagai unit dasar pengembangan yang tergantung kepada redistribusi otoritas pengambilan keputusan (OERI, 1994). Sekolah/Madrasah merupakan institusi yang memiliki "full authority and responsibility" (Grinshtain \& Gibson, 2017). Prinsip yang dikembangkan adalah kemandirian, kemitraan, partisipasi, keterbukaan dan akuntabilitas.

Partisipasi sebagai salah satu prinsip MBS merupakan hal mendasar dalam penyelenggaraan pendidikan. Dengan partisipasi (tenaga, pikiran, dana maupun sarana) dalam perencanaan, pelaksanaan dan penilaian kegiatan sekolah/madrasah dapat membangun tanggung jawab bersama terhadap proses dan hasil pendidikan (Tilaar, 2002). Salah satu partisipan penting di sekolah/madrasah adalah guru, termasuk di dalamnya partisipasi dalam perencanaan kegiatan dan penganggaran. Keterlibatan guru menjadikan dirinya memahami peran dan risiko, sehingga mampu menumbuhkan rasa tanggung jawab terhadap proses dan pelaksanaan pendidikan di sekolah (Fuad, 2015). Partisipasi guru baik secara parsial maupun simultan memiliki pengaruh terhadap implementasi rencana kerja madrasah. Partisipasi guru membantu memastikan koordinasi keputusan yang lebih besar antara guru dan kepala sekolah (Mbowane et al., 2017).

Kabupaten Karawang merupakan salah satu kabupaten dengan dinamika pembangunan yang pesat di wilayah Provinsi Jawa Barat. Sebagai daerah yang disiapkan sebagai Kawasan Industri Modern terbesar di Asia Tenggara (Keppres No. 53, Tahun 1989). Karawang ditandai dengan tingkat pertumbuhan kawasan industri, bisnis perdagangan, dan bisnis jasa yang sangat cepat dan kompleks. Kondisi ini melahirkan pergeseran pola aktivitas kehidupan sosialekonomi dan sosial-budaya masyarakat. Pada aspek sosial-ekonomi, termasuk pesatnya pertumbuhan perumahan, yang berdampak terhadap kebutuhan akan ketersediaan lembaga pendidikan. Keterbatasan pemerintah dalam penyediaan lembaga pendidikan (sekolah) sesuai kebutuhan, direspons masyarakat dengan pendirian berbagai jenjang pendidikan, diantaranya adalah jenjang pendidikan dasar berciri khas agama Islam, utamanya Madrasah Ibtidaiah Swasta (MIS). Pertumbuhan MIS dalam setiap tahunnya meningkat secara signifikan. Pada tahun 2010 terdapat 132 MIS, pada tahun 2015 menjadi 138, dan pada tahun 2020 menjadi 143 (Kemenang, 2020).

Tingkat pertumbuhan MIS yang begitu pesat di Kabupaten Karawang, menjadikan MIS sangat kompetitif dalam merebut minat masyarakat. Namun berdasar hasil wawancara, FGD dengan para pengawas serta para pejabat di lingkungan Kemenag Kabupaten Karawang, serta beberapa penyelenggara MI (Yayasan), pada umumnya MIS memiliki masalah dengan manajemen kelembagaan, terutama dalam penetapan rencana kegiatan dan anggaran yang belum memartisipasikan guru secara optimal.

Banyaknya keluhan MIS yang merasa kesulitan dalam menyusun RKAM, diakibatkan rendahnya sumber daya manusia MIS yang sering mengakibatkan terlambatnya pencairan BOS di MIS. Melalui survei pendahuluan terhadap beberapa MIS yang ada di Kecamatan Klari Kabupaten Karawang, mengindikasikan : (1) Rencana Kegiatan dan Anggaran (RKA) di MIS pada umumnya merupakan otoritas kepala sekolah sebagai panjang tangan birokrasi pemerintah dan konsekuensi penerima dana Biaya Operasional Sekolah (BOS); (2) Guru merasa tidak memahami rencana kegiatan dan anggaran di tempat mereka bekerja; (3) Guru menganggap penetapan kegiatan dan anggaran bukan tanggung jawab dirinya. Implikasinya, MIS kurang mendapatkan dukungan guru dalam implementasi rencana sekolah (Nurhattati, 2017). Selain itu, pada umumnya guru lebih dipartisipasikan dalam pembelajaran, untuk melakukan transformasi pengetahuan, nilai, dan keterampilan kepada siswa. Keadaan seperti itu tentu tidak dapat terus berlangsung, 
mengingat semakin besarnya kewenangan MI untuk mengelola dirinya sendiri, serta butuhnya dukungan guru terhadap kepala sekolah dalam menyusun Rencana Kegiatan Anggaran Madrasah (RKAM). Dalam hal ini guru dituntut mampu mengubah keberadaan dirinya yang semula kiprahnya terbatas bekerja di ruang kelas, harus berkiprah dalam kelembagaan madrasah. Guru dituntut untuk terlibat secara kelembagaan, sehingga merasa menjadi bagian dari kemajuan sekolah/madrasah di tempat mereka bekerja. Indikasi rendahnya partisipasi guru dalam RKAM MIS di Kabupaten Karawang di satu sisi, serta pentingnya partisipasi guru dalam penetapan RKAM pada sisi lain, dan belum adanya sistem partisipasi dalam penyusunan RKAKM menarik penulis untuk mengeksplorasi lebih jauh partisipasi guru dalam RKAM pada MIS di wilayah Kabupaten Karawang.

Penelitian bertujuan mengeksplorasi realitas partisipasi guru dalam penetapan RKAM mencakup: (1) tingkat pemahaman guru terhadap RKAM, peran dirinya dalam perencanaan dan penganggaran, serta pengoperasian aplikasi penganggaran dan laporan pertanggungjawaban; (2) tingkat partisipasi guru dalam penetapan visi, misi, dan nilai madrasah, pemetaan masalah madrasah, penetapan tujuan, sasaran dan target madrasah, penetapan kegiatan madrasah dan penetapan anggaran; serta (3) Faktor-faktor yang mempengaruhi partisipasi guru dalam RKAM. Melalui temuan terhadap fakta yang ada, dilakukan pendalaman guna merumuskan gagasan solutif strategi peningkatan partisipasi guru dalam menjembatani terwujudnya kelembagaan dengan manajemen berbasis sekolah di MIS.

Penelitian diharapkan secara teoretis menghasilkan konsep optimalisasi partisipasi guru dalam RKAM dalam mewujudkan transparansi pengelolaan madrasah. Secara praktis diharapkan dapat memberi masukan pada MIS dalam melakukan peningkatan partisipasi guru, serta menghasilkan rumusan strategi pemartisipasian guru yang dapat digunakan pihak pembina madrasah dalam optimalisasi MBS di MIS, serta memberikan masukan pada pemerintah untuk membuat sistem pemartisipasian guru dalam RKAM.

\section{KAJIAN TEORI}

\section{Rencana Kegiatan dan Anggaran Madrasah (RKAM)}

Rencana merupakan pernyataan tentang tujuan yang ditetapkan organisasi dan keputusan tentang bagaimana cara terbaik dalam pencapaiannya (Griffin, 2020). Secara lebih luas, rencana adalah keputusan tentang tujuan, kegiatan, serta bagaimana cara atau strategi untuk mencapainya. Rencana dirumuskan secara rasional dan sistemik, mengandung seperangkat tujuan, kegiatan yang akan dilakukan, sumber daya yang digunakan, metode dan cara yang dipakai untuk pencapaiannya (Nurhattati, 2015).

Rencana kegiatan sebagai rencana operasional tahunan (action plan) untuk periode satu tahun, dengan format laporan pimpinan kepada pemangku kepentingan berdasarkan kerangka perencanaan (Davies \& Ellison, 2003). Sebagai rencana operasional tahunan, disusun melalui tahapan: (1) identifikasi kebutuhan guna mengetahui kesenjangan antara keinginan dan kenyataan guna perumusan masalah; (2) Penetapan skala prioritas dan pilihan kegiatan yang akan dilakukan; (3) Penetapan kegiatan yang akan dilaksanakan; (4) Penetapan anggaran dan (5) Penetapan strategi pencapaiannya (Matin, 2013). Rencana kegiatan mengandung unsur : (1) tujuan yang ingin dicapai, dalam hal ini terkait dengan mutu pendidikan; (2) Kegiatan yang harus dilakukan untuk mencapai tujuan; (3) cara pelaksanaan kegiatan; (4) orang yang dilibatkan dalam pencapaian tujuan; (5) waktu dan tempat kegiatan; (6) peralatan dan sarana apa yang digunakan; (7) Anggaran yang dibutuhkan untuk pelaksanaan kegiatan; (8) alat ukur yang digunakan untuk melihat keberhasilan (Fuad, 2015). Agar rencana kegiatan berfungsi dengan baik, hendaknya: (1) masuk akal dan mudah dilaksanakan; (2) menggambarkan realitas yang sesungguhnya dan tingkat kepastian dan ketercapaiannya; (3) memberikan gambaran fungsi, tugas, wewenang dan tanggung jawab serta prosedur kerja; dan (4) memberikan arahan dan gambaran hasil yang akan dicapai (Fuad, 2015).

Dalam konteks madrasah, rencana kegiatan mencakup: (1) kegiatan akademik/kurikulum yang terbagi dalam 
kegiatan intra-kurikuler-pembelajaran terjadwal, kokurikuler yang erat kaitannya dengan pengayaan intra kurikuler, dan kegiatan ekstra kurikuler untuk pengembangan minat bakat siswa; (2) kegiatan administratif sekolah sebagai penunjang berlangsungnya kegiatan pengajaran merupakan proses pengaturan terhadap seluruh komponen sekolah seperti siswa, para guru, karyawan, sarana dan prasarana, keuangan, hubungan masyarakat dan sebagainya. Dalam prosesnya, rencana kegiatan madrasah disusun sepanjang waktu melalui tahapan: (1) analisis visi, misi dan nilai untuk menginspirasi penyusunan rencana; (2) inventarisasi kebutuhan (need assessment) untuk memperoleh informasi akurat tentang segala kebutuhan terkait penyelenggaraan pendidikan di madrasah; (3) penetapan tujuan, sasaran, dan target yang ingin dicapai; (4) menetapkan kegiatan mencakup: ruang lingkup kegiatan, sumber yang akan digunakan; waktu dan tempat kegiatan, pihak yang terlibat, serta anggaran yang dibutuhkan (Permendiknas, 2007).

RKAM dalam penyusunannya diawali dengan analisis visi, misi dan nilai madrasah. Visi merupakan wawasan jauh ke depan yang menunjukkan arah bagi pencapaian tujuan, atau disebut juga sebagai impian keadaan madrasah di masa yang akan datang. Visi memiliki fungsi sebagai: (1) arah atau pedoman dalam pengambilan keputusan, (2) menyatukan pandangan tentang keberadaan dan upaya pencapaian tujuan, (3) menjadi muara bagi setiap kegiatan (Indrajit, 2008). Misi merupakan tindakan atau kegiatan yang diemban untuk mewujudkan visi. Nilai berkaitan dengan harga, kebaikan, kebenaran, keindahan atau sebaliknya. Nilai dapat dikatakan sebagai norma yang dijadikan pedoman dalam melaksanakan misi dan merealisasikan visi. Nilai yang disebut sebagai "kredo" atau falsafah organisasi. Nilai merupakan sesuatu yang tertanam dalam jiwa seluruh anggota organisasi yang melandasi setiap tingkah karyawan/pegawai (Nurhattati, 2015). Setiap madrasah harus memiliki visi, misi dan nilai. Dengan visi tergambar arah yang dituju. Dengan misi diketahui tindakan apa yang harus diemban/dilakukan. Dengan nilai setiap masalah yang timbul dapat diselesaikan sesuai ketentuan. Dalam perumusannya tentu harus melibatkan guru dan staf sehingga mereka bertanggung-jawab dalam implementasinya

Langkah kedua adalah pemetaan masalah atau inventarisasi kebutuhan sebagai proses menghimpun dan mempelajari persoalan yang ada agar apa yang direncanakan tergambar keberadaannya (Suharto, 1997). Pemetaan masalah madrasah dilakukan berdasar delapan standar, yang terdiri dari: kompetensi, isi, proses, penilaian, pembiayaan, sarana dan prasarana ketenagaan dan penyelenggaraan) dengan menggunakan Evaluasi Diri Madrasah (EDM). Hasil EDM merupakan gambaran keberadaan serta masalah masing-masing standar di madrasah. Pemetaan masalah selain diperoleh melalui EDM, juga diperoleh dari hasil analisis terhadap kegiatan yang tidak terealisasi pada tahun sebelumnya. Hasil EDM dalam bentuk peta permasalahan dibuat ke dalam skala prioritas untuk ditetapkan sebagai kegiatan di tahun mendatang. Penetapan prioritas, disusun berdasarkan panduan yang ditetapkan Kemenag.

Langkah ketiga adalah penetapan tujuan yang ingin dicapai atau dihasilkan pada waktu yang ditentukan. Tujuan ditetapkan untuk mencapai kinerja yang diharapkan (Sakaran, 2006). Tujuan berfungsi memberi arah dan pedoman dalam penetapan dan pelaksanaan kegiatan, sebagai alat kontrol dan penentu keberhasilan. Maryati membuktikan bahwa ketepatan rumusan tujuan berpengaruh terhadap ketepatan penetapan anggaran yang berimplikasi terhadap kinerja manajerial (Maryanti, 2009). Oleh karena itu, tujuan hendaknya dirumuskan dengan mempertimbangkan kebutuhan berbagai pihak seperti pemerintah, orang tua/masyarakat, dan warga madrasah itu sendiri (siswa, pimpinan, yayasan, guru dan tenaga kependidikan. Selain itu tujuan, sasaran dan target harus realistis, dimengerti dan dapat dilaksanakan (implementable).

Langkah keempat adalah penetapan kegiatan secara rinci dengan segenap pendukungnya baik manusia maupun non manusia untuk mencapai tujuan/sasaran. Setiap kegiatan menggambarkan jenis kegiatan, bagaimana kegiatan dilakukan, alokasi waktu yang digunakan, alokasi biaya yang digunakan, 
pelaksana kegiatan, serta sarana yang dibutuhkan untuk pelaksanaannya.

Langkah ke lima adalah penetapan anggaran sebagai aktivitas penyusunan rencana secara sistematis dalam bentuk moneter yang meliputi seluruh kegiatan dalam sebuah organisasi untuk jangka waktu tertentu di masa yang akan datang. Dengan kata lain penganggaran sebagai proses menghargakan kegiatan dalam moneter. Anggaran berfungsi sebagai pedoman pelaksanaan dan pengoordinasian kegiatan, selain berfungsi sebagai ilustrasi dan penggambaran moneter untuk melakukan kegiatan sehingga rencana dan kegiatan terarah sesuai tujuan yang ditetapkan. Anggaran bermanfaat dalam menumbuhkan tanggung-jawab pegawai, mengarahkan kegiatan organisasi, menghindari pemborosan, mengetahui kelemahan organisasi, dan sebagai alat evaluasi kegiatan.

\section{Partisipasi Guru Dalam Perencanaan dan Anggaran}

Participation is defined as mental and emotional involvement of a person in a group situation which encourage him to contribute to group goals and share responsibility in them (Newstrom, 2015). (Zheng et al., 2019) menyebut partisipasi sebagai keterlibatan mental dan emosional orang-orang dalam suatu kelompok yang mendorong mereka untuk memberikan kontribusi pada tujuan kelompok dengan berbagai tanggung jawab dalam pencapaian tujuan itu. Dengan demikian, partisipasi merupakan keterlibatan mental dan emosional individu dalam situasi kelompok secara aktif dan sukarela baik secara intrinsik maupun ekstrinsik dalam mendorong dan menyokong serta bertanggung jawab terhadap pencapaian tujuan kelompok.
Sumaryadi mengelompokkan partisipasi ke dalam bentuk pengambilan keputusan dan pembuatan kebijakan, tenaga, waktu, keahlian, modal dan atau materi. (Sumaryadi, 2010, Ndekha, Molgaard, P, \& Furu, 2003). Dilihat dari prosesnya partisipasi dilakukan pada saat : (1) pengambilan keputusan, (2) pelaksanaan keputusan, (3) pengambilan manfaat dan (4) evaluasi pelaksanaan (Arnstein, 2007). Partisipasi ke dalam tiga hal, yaitu : (1) Gagasan/pikiran yang memungkinkan diperolehnya keputusan yang benar sehingga dapat meningkatkan kemampuan anggota, membangun komunikasi dua arah, dan mendorong anggota untuk bertanggung jawab; (2) Tenaga, dana dan sarana yang mampu melahirkan rasa pemilikan dan menumbuhkan rasa tanggung jawab terhadap organisasi (Rudito \& Budiman, 2003). Oleh karena itu, partisipasi bermanfaat untuk menyalurkan hasrat mengontrol, meningkatkan perasaan membantu dan tanggung jawab serta mengurangi perasaan terasing dan anonimitas. (Wandersman \& Florin, 2000).

Dalam konteks madrasah, partisipasi merupakan proses warga madrasah (termasuk guru, orang tua dan masyarakat) terlibat aktif baik secara individual maupun kolektif, secara langsung maupun tidak langsung dalam pengambilan keputusan, pembuatan kebijakan, perencanaan, pelaksanaan, pengawasan atau pengevaluasian pendidikan di madrasah. Studistudi tentang partisipasi penyelenggaraan sekolah mengonstruksi keterlibatan segenap unsur terkait dengan pembelajaran di sekolah, yang meliputi komite sekolah, kepala sekolah, guru, orang tua, masyarakat pengguna pendidikan dalam pembuatan keputusan (Gambar 1).

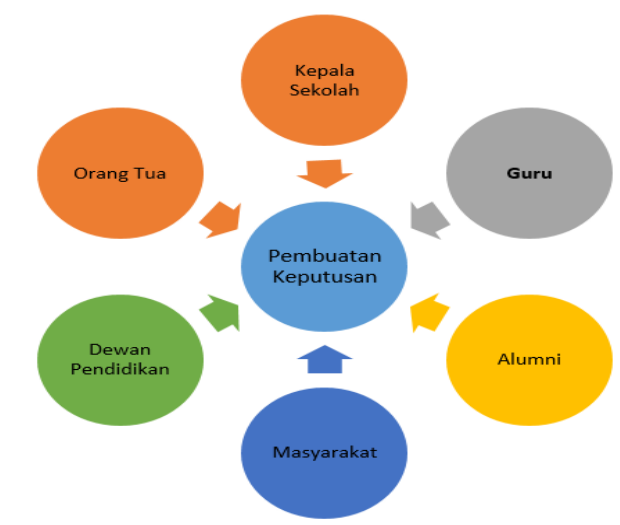

Gambar 1. Partisipasi dalam Pembuatan Keputusan (Hasil Pemikiran Penulis) 
Dengan demikian, secara teoretis, partisipasi madrasah merupakan pelibatan segenap unsur penyelenggaraan madrasah, yang meliputi : Komite madrasah, kepala madrasah, guru, orang tua, dan masyarakat pengguna layanan pendidikan madrasah untuk terlibat dalam proses pembuatan keputusan. Partisipasi di madrasah bertujuan : (1) menampung aspirasi dan prakarsa warga sekolah dalam melahirkan kegiatan operasional sesuai kebutuhan; (2) memperoleh dukungan dalam implementasi kegiatan; (3) meningkatkan tanggung jawab dan peran warga sekolah dalam penyelenggaraan pendidikan; (4) menciptakan suasana dan kondisi transparansi, akuntabel, dan demokratis dalam penyelenggaraan dan pelayanan pendidikan; (5) meningkatkan kemampuan lembaga dalam melakukan administrasi (Suryosubroto, 2001; Tilaar, 2002).

(Herminingsih, 2009), menemukan bahwa partisipasi pegawai dalam penganggaran berefek terhadap keterlibatannya dalam pelaksanaan program yang berpengaruh terhadap kinerja lembaga. Bahkan Newsrtrom menyebut "participation tends to improve performance and job-satisfaction, has an effect on both satisfaction and productivity, tends to improve motivation, because employees feel more accepted and involved in the situation." Dengan demikian partisipasi guru dalam penganggaran merupakan hal penting agar terbangun kesadaran untuk turut memastikan penganggaran dialokasikan dengan tepat sesuai kebutuhan, dioperasikan sesuai ketentuan, sehingga dapat menjamin ketercapaian tujuan.

Dalam setiap tahapan manajerial madrasah, termasuk dalam penetapan kegiatan dan anggaran hendaknya memartisipasikan guru. Hal tersebut karena partisipasi guru dapat: (1) meningkatkan pemahaman guru tentang bagaimana rencana didesain; mengembangkan inisiatif dan tanggung-jawab guru terhadap apa yang direncanakan; (3) meningkatkan motivasi guru untuk terlibat secara intensif dalam implementasi rencana; (4) Membangun komitmen guru yang tinggi dalam implementasi rencana; (5) mengembangkan "self managing-team" guru, sehingga mempermudah dalam pengoperasian rencana; (6) mengefektifkan evaluasi dan monitoring ketercapaian rencana. (Fuad, 2015). Partisipasi dalam sebuah perencanaan menumbuhkan komitmen dan tanggung jawab sosial untuk mengimplementasikan dan mengupayakan segala hal yang dibutuhkan demi tercapainya tujuan yang telah ditetapkan "successful planning and teaching require a dialectic between expertise and broad participation" (Kennedy \& Tilly, 2019). di sekolah/madrasah.

\section{METODOLOGI}

Penelitian yang dilaksanakan pada bulan Agustus sampai dengan bulan September tahun 2019 pada MIS di Kabupaten Karawang, menggunakan metode survei yang memberi keleluasaan memperoleh temuan-temuan penelitian berupa data-data yang bersifat kuantitatif maupun kualitatif (Sevilla, 1988). Penelitian dilaksanakan melalui tahapan: (1) perumusan masalah, (2) penentuan sampel dan rencana sampling, (3) penyusunan instrumen, (4) pengumpulan dan analisis data, dan (5) pelaporan (Kerlinger, 1996). Secara rinci penelitian dilakukan melalui Langkah sebagai berikut.

Langkah awal, dirumuskan masalah penelitian yang terdiri dari: (1) Seberapa tinggi pemahaman guru terhadap RKAM? Seberapa tinggi partisipasi guru dalam penetapan RKAM? (3) Faktor-faktor apa saja yang mempengaruhi partisipasi guru dalam RKAM ? (4) Bagaimana strategi peningkatan partisipasi guru dalam menjembatani terwujudnya MBS di MIS ?

Langkah kedua menentukan unit analisis penelitian adalah guru MIS. Dengan demikian ditetapkan populasi penelitian adalah seluruh guru MIS yang berada di Kabupaten Karawang yang tersebar di 30 Kecamatan. Terdiri dari 14 MIS, dengan jumlah guru sebanyak 1227 orang. Sampel ditetapkan dengan menggunakan penghitungan rumus Slovin.

\begin{tabular}{ll|}
\multicolumn{2}{c}{2201} \\
\hline 1 & +2201 \\
\hline 1 & $+1227(0,05)^{2}$ \\
\multicolumn{2}{c}{$1227(0,0025)$} \\
\hline 1 & +1227 \\
\multicolumn{2}{|c|}{3,0} \\
$=$ & 4,0 \\
\hline \multicolumn{2}{|c}{301}
\end{tabular}

Berdasarkan perhitungan di atas, dapat diketahui bahwa sampel penelitian berjumlah 301 guru. Penetapan sampel dilakukan melalui 
langkah: (1) Penetapan wilayah populasi ke dalam 4 zona, yaitu Timur, Barat, Utara dan Selatan; (2) Penetapan jumlah sampel dengan penghitungan slovin; (3) Penetapan jumlah responden sesuai unit analisis yang terbagi ke dalam 4 zona; (4) Penetapan responden yang dilakukan secara acak dari masing-masing MIS. Selain itu ditetapkan responden tambahan untuk memberi penguatan/konfirmasi terhadap temuan penelitian yang terdiri dari: Kasi Madrasah, Pengawas Madrasah, Pengurus yayasan dan beberapa Kepala Sekolah dari keempat zona.

Langkah ketiga adalah penetapan instrumen penelitian. Instrumen yang digunakan adalah angket dalam bentuk skala sikap yang dituangkan dalam Google form, Skala sikap digunakan untuk memperoleh informasi terkait dengan (1) Persepsi guru tentang pemahamannya terhadap rencana kegiatan, penganggaran, penggunaan aplikasi eanggaran dan pertanggung-jawaban;

Tingkat partisipasi dalam analisis visi, misi, nilai, pemetaan masalah, penetapan skala prioritas dan kegiatan, penganggaran dan penetapan strategi pencapaian; (3) Faktor yang mempengaruhi partisipasi guru berdasarkan identitas responden. Angket disebar terhadap seluruh responden sesuai sampel yang ditetapkan. Untuk memperkaya data digunakan studi dokumentasi, wawancara terstruktur melalui video call serta Focus Group Discussion (FGD) secara daring.

Langkah keempat adalah pengolahan dan analisis secara kuantitatif dalam bentuk persentase yang dituangkan dalam tabel, diagram dan grafik. Data kualitatif, dilakukan coding dan direduksi, dilakukan triangulasi, sehingga keduanya saling melengkapi dan memperkaya hasil penelitian. Data yang diperoleh tersebut selanjutnya ditulis dalam bentuk laporan penelitian.

\section{HASIL DAN PEMBAHASAN}

\section{Pemahaman Guru Terhadap Rencana Kegiatan dan Anggaran Madrasah (RKAM)}

Seorang individu (termasuk guru) akan mampu berpartisipasi bila memiliki wawasan dan motivasi serta minat berpartisipasi (Zheng et al., 2019). Oleh karena itu sebelum memaparkan partisipasi guru dalam penyusunan RKAM, terlebih dahulu dipaparkan persepsi guru terkait pemahamannya terhadap RKAM (penganggaran, penggunaan $e$ anggaran, serta pelaporan dan pertanggung jawaban). Pemahaman terhadap hal yang dipartisipasikan (RKAM) sangat berkaitan dengan kesediaan guru berpartisipasi dalam penyusunan RKAM.

Hasil penelitian menunjukkan, hampir $76 \%$ guru memersepsi dirinya tidak memahami rencana kegiatan di tempat mereka mengajar, $14,4 \%$ guru terkategori kurang memahami, dan hanya $4,6 \%$ guru yang mengakui sangat memahami dan sisanya sebesar $7 \%$ tidak menjawab tingkat pemahamannya tentang rencana kerja di MI tempat mereka mengajar. Mereka yang terkategori sangat memahami adalah kepala sekolah, bendahara, operator dan guru yang ditunjuk pengisi EDM. Dengan demikian secara umum atau sebagian besar mencapai 90\% lebih guru MIS di Kabupaten Karawang kurang bahkan cenderung tidak memahami rencana kegiatan madrasah.

Selanjutnya pemahaman guru terhadap penganggaran di madrasah tempat mereka bekerja juga menunjukkan tingkat rendah. Hanya lebih tinggi dibanding pemahamannya terhadap rencana kegiatan madrasah. Sebanyak $63 \%$ guru tidak memahami penganggaran di tempat mereka mengajar. Hanya $6,1 \%$ yang merasa dirinya sangat memahami penganggaran. Sama seperti sebelumnya hanya tim RKAM yang menyatakan sangat memahami anggaran di madrasahnya.

Selanjutnya, tingkat pemahaman guru terhadap penggunaan aplikasi anggaran pun sangat memprihatinkan. Hal tersebut ditunjukkan dengan $75,3 \%$ guru menyatakan dirinya tidak paham tentang aplikasi $e$ anggaran (penganggaran berbasis aplikasi elektronik). Bahkan tidak mampu sama sekali mengoperasikannya. Guru menganggap tidak perlu memahami dan mampu mengoperasikan aplikasi e-anggaran, karena bukan wilayah pekerjaan mereka. Kurang dari 5\% guru menyatakan sangat paham dan mampu mengoperasikan aplikasi e-anggaran. Sama seperti sebelumnya hanya tim RKAM yang paham dan mampu mengaplikasikan RKAM. Tidak begitu berbeda keadaannya, pemahaman guru terhadap laporan pertanggung-jawaban 
RKAM pun dalam kategori rendah pula. Sebanyak $71,9 \%$ guru menyatakan tidak paham sama sekali dengan laporan pertanggungjawaban penggunaan anggaran di madrasah tempat mereka kerja. Mereka merasa tidak perlu memahaminya. Mereka meyakini bahwa sesuai tugas \& tanggung jawabnya, yang terpenting adalah melaksanakan tugas mengajar dengan baik, dan hak-hak guru terbayar. Secara lengkap pemahaman guru MIS terhadap rencana kegiatan, penganggaran, e-anggaran dan laporan pertanggung-jawaban di tempat mereka bekerja (Gambar 2).

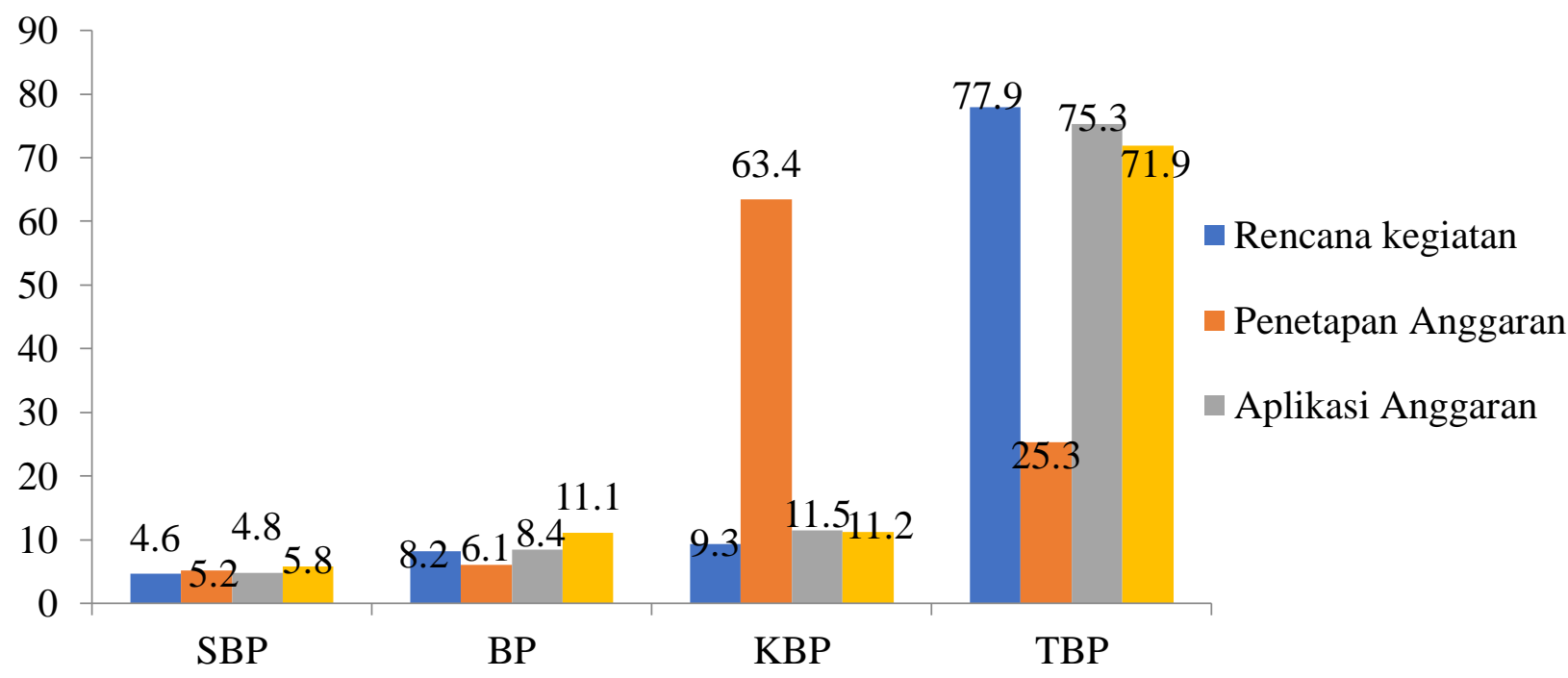

Gambar2. Persepsi Guru Tentang Pemahamannya Terhadap RKAM

Uraian di atas diperkuat dengan hasil FGD dengan Pengawas, Kepala Seksi Madrasah dan beberapa Kepala Sekolah yang menyatakan bahwa tingkat pemahaman guru terhadap RKAKM rendah. Hal tersebut karena RKAM bukan merupakan tanggung-jawab guru, tapi tanggung-jawab TIM RKAM di madrasah masing-masing. Hampir seluruh MIS tidak mensosialisasikan RKAM pada para guru. Hanya satu MIS yang mensosialisasikan, yaitu MIS Al 'Istiqlal Klari.

Dapat diprediksi, tingkat pemahaman guru terhadap RKAM yang rendah, berimplikasi terhadap tingkat partisipasi guru dalam penetapan rencana kegiatan dan anggaran yang pada gilirannya berdampak terhadap kurang efektifnya implementasi rencana dan anggaran. Dengan demikian, harapan terjadinya transparansi pengelolaan madrasah sulit terwujud. Dalam upaya menumbuhkan kesadaran guru tentang pentingnya RKAM, perlu dilakukan perubahan mind set guru sebagai profesi yang hanya bertanggung jawab pada pembelajaran semata, namun guru juga bertanggung-jawab terhadap penyelenggaraan manajemen sekolah/madrasah dalam segenap dimensinya. Hanya saja, secara psikekultural, mengubah mind-set atau cara berpikir guru diperlukan berbagai pendekatan (multi-approach), dengan cara memaksa mengubah pikiran, dengan membantu mereka melihat kebenaran yang dilakukan secara evolusi melalui pendekatan rasional-ilmiah maupun humanis-emosional. Demikian pula, untuk membangun partisipasi perlu waktu yang cukup, selain perlu meningkatkan pengetahuan dan menumbuhkan minat yang memadai. (Zheng et al., 2019).

\section{Partisipasi Guru dalam Penyusunan RKAM}

Dalam operasionalnya, partisipasi di madrasah bertumpu pada guru, karena guru merupakan pelaku utama pendidikan di madrasah. Tanpa partisipasi guru dalam segenap aspek kelembagaan madrasah baik dalam perencanaan, pengorganisasian, maupun pengawasan, sangat tidak mungkin tujuan pendidikan dapat dicapai. Untuk itu, dalam penelitian ini akan dipaparkan secara berurutan terkait dengan partisipasi guru dalam: (1) analisis visi, misi dan nilai; (2) penetapan tujuan, sasaran dan target; (3) pemetaan masalah dan skala prioritas; (4) penetapan kegiatan, (5) penetapan strategi pencapaian. 
Partisipasi guru dalam menganalisis visi, misi, nilai madrasah

Hasil FGD menunjukkan, bahwa MIS di wilayah Kabupaten Karawang pada umumnya merumuskan visi, misi, dan nilai, semata untuk memenuhi dokumen kurikulum, akreditasi, dan dokumen administrasi lainnya. Rumusan visi, misi dan nilai belum merupakan hasil evaluasi terhadap keadaan internal maupun eksternal yang dilakukan bersama, namun sekedar memenuhi persyaratan manajemen. Sebagian besar guru $(67,1 \%)$ tidak berpartisipasi dalam perumusan visi, misi dan nilai. Perumusan cenderung dilakukan pimpinan (Kepala sekolah), dengan memodifikasi atau bahkan meniru madrasah lain. Keadaan tersebut berefek terhadap ketidakjelasan pemeranan guru dalam manajemen kelembagaan yang berdampak terhadap tidak optimalnya pelaksanaan kegiatan di madrasah. Selain itu suasana dan kondisi transparansi, akuntabilitas, dan demokratisasi dalam penyelenggaraan dan pelayanan pendidikan sulit diwujudkan, selain kemampuan lembaga dalam melakukan administrasi pun sulit diwujudkan pula. Secara lengkap partisipasi guru dalam perumusan visi, misi dan nilai dapat dilihat pada Gambar 3 .

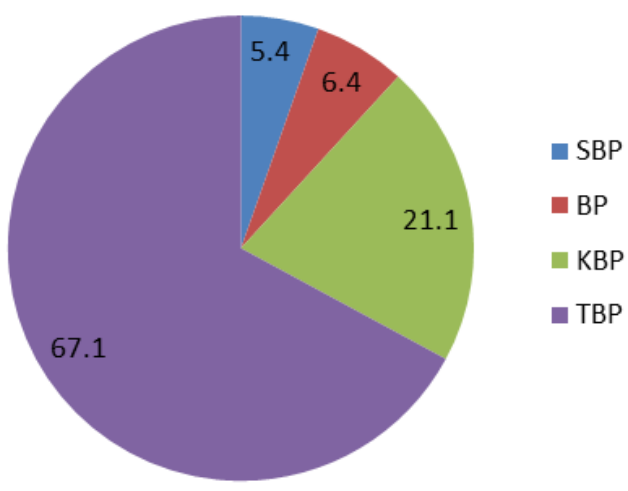

Gambar 3. Partisipasi Guru dalam Penetapan Visi, Misi dan Nilai di MIS

\section{Partisipasi Guru dalam Pemetaan masalah}

Tingkat partisipasi guru dalam pemetaan masalah di MIS dalam kategori sangat rendah. $69,2 \%$ guru menyatakan tidak berpartisipasi sama sekali. 21,3 \% kurang berpartisipasi. Hanya $4,9 \%$ yang menyatakan sangat berpartisipasi. Pada umumnya yang berpartisipasi adalah guru yang ditunjuk sebagai pengisi EDM, bendahara dan operator. Sementara guru lainnya adalah yang membantu dalam pengisian EDM. Secara diagramatik, partisipasi guru dalam pemetaan masalah di MIS dapat dilihat pada Gambar 4.

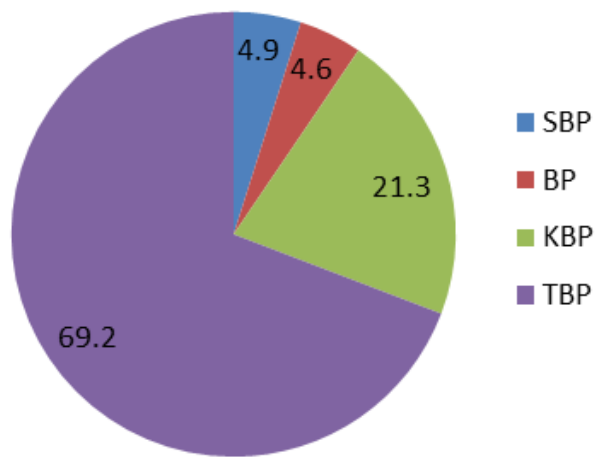

Gambar 4. Partisipasi Guru dalam Pemetaaan Masalah

\section{Partisipasi guru dalam penetapan tujuan, sasaran, dan target}

Partisipasi guru dalam perumusan tujuan, sasaran dan target sangat penting, karena seseorang yang berpartisipasi dalam organisasi, akan memiliki komitmen pada tujuan (Robbins
\& Judge, 2017). Seseorang yang berpartisipasi dalam perencanaan, akan memiliki komitmen untuk berpartisipasi dalam implementasi rencana, yang berdampak terhadap dimungkinkannya tujuan dapat tercapai. Dalam prosesnya, penetapan tujuan, sasaran dan target di MIS yang diteliti seperti yang terungkap 
dalam hasil FGD, umumnya ditetapkan berdasarkan skala prioritas sesuai hasil pemetaan permasalahan yang telah disusun Tim RKAM.

Guru MIS di Kabupaten Karawang, sebagian besar $(68,3 \%)$ tidak terlibat $(68,3 \%)$, bahkan tidak memiliki kesempatan memberi masukan, perbaikan/penyempurnaan terhadap tujuan, sasaran dan target sesuai permasalahan yang mereka alami. Hanya $5,5 \%$ yang menyatakan sangat terlibat. Mereka pada umumnya Tim RKAM. Di beberapa MIS bahkan ditemukan, adanya keterlibatan Yayasan. Sebenarnya Yayasan tidak berkewenangan menyusun RKAM. Sebagai penyelenggara, Ia berfungsi memberi arah, menyediakan sarana dan dana serta mengontrol implementasi kegiatan madrasah. Secara lengkap partisipasi guru dalam penetapan tujuan, sasaran, target dapat dilihat pada Gambar 5.

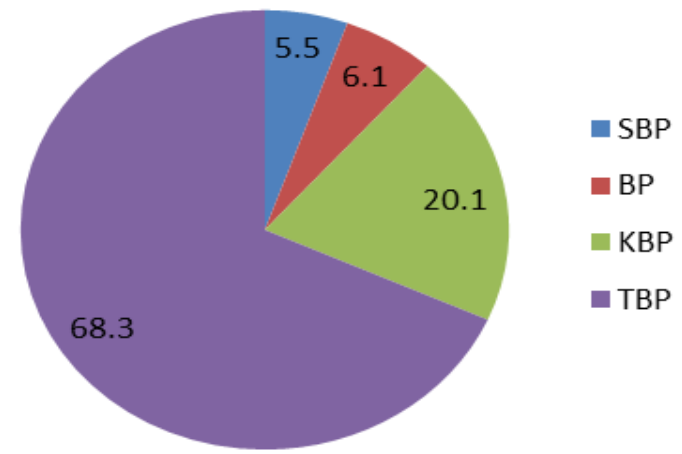

Gambar 5. Partisipasi Guru dalam Penetapan Tujuan, Sasaran dan Target

\section{Partisipasi guru dalam penetapan kegiatan madrasah}

Penetapan kegiatan menggunakan format yang diisi secara online berdasarkan hasil EDM. Komponen kegiatan terdiri: kurikulum dan pembelajaran, sarana, ketenagaan, hubungan sekolah dan masyarakat, yang pendanaannya bersumber dari BOS. Tingkat partisipasi guru dalam penetapan kegiatan madrasah terkategori rendah. Terindikasi sebanyak $68 \%$ menyatakan tidak terlibat dalam penetapan segenap aspek kegiatan, terutama dalam penetapan anggaran dan pemetaan masalah. Namun sebanyak $62 \%$ terlibat dalam penetapan kegiatan kurikulum dan pembelajaran (penetapan tujuan, materi, metode dan penilaian). Hal ini karena guru merupakan individu yang bersentuhan langsung dengan pembelajaran.

Dalam penetapan struktur program, beban belajar dan kalender pendidikan, partisipasi guru dalam kategori rendah pula (64\% guru menyatakan kurang terlibat). Hasil FGD menunjukkan guru memersepsi hal tersebut di atas merupakan otoritas pimpinan. Guru cukup mengikuti apa yang ditetapkan pimpinan. Begitu juga dalam penetapan kegiatan kelembagaan, seperti pembagian tugas, pelayanan masyarakat, membangun citra dan pengembangan mitra, juga dalam kategori rendah. Masalah kelembagaan dipersepsi guru sebagai wilayah pimpinan. Hal ini sebenarnya merupakan maslah dalam kelembagaan di MI, karena tidak terlibatnya dalam kelembagaan berdampak terhadap sulitnya kepala sekolah dalam mengoperasional manajemen operasional di MIS.

Dalam penetapan kegiatan kesiswaan, sebanyak $52 \%$ menyatakan tidak berpartisipasi. $48 \%$ kurang berpartisipasi dalam penetapan kegiatan ekstra kurikuler, bimbingan konseling dan penanganan masalah siswa. Namun demikian, partisipasi tersebut hanya berupa masukan. Penetapan kegiatan tetap menjadi otoritas tim RKAM. Pada MIS tertentu, yayasan terlibat dalam penetapan kegiatan kesiswaan, yang sebenarnya bukan kewenangan mereka. Keterlibatan yayasan dalam hal tersebut, selain faktor ketidakpercayaan terhadap tim RKAM, juga terdapatnya rangkap jabatan sebagai pengurus yayasan, sekaligus sebagai kepala sekolah. Kondisi ini seharusnya tidak terjadi, karena akan berdampak terhadap ketidakmandirian madrasah dalam mengelola dirinya sesuai yang diamanatkan MBS. Selain itu, menjadikan Yayasan sebagai penyelenggara kurang berfungsi secara optimal. Secara lengkap partisipasi guru dalam penetapan kegiatan dapat dilihat pada gambar di bawah ini. 


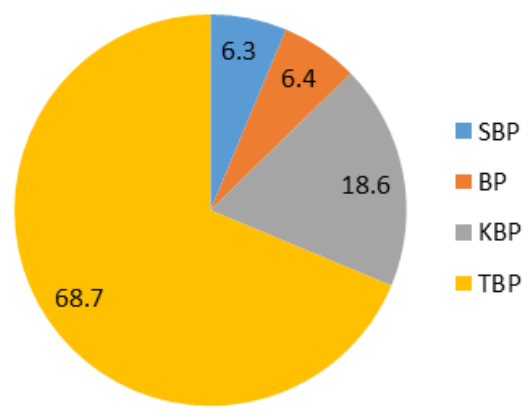

Gambar 6. Partisipasi Guru dalam Penetapan Kegiatan

Berdasar hasil FGD Prioritas program pada setiap MIS dari tahun ke tahun relatif sama. Implikasinya, pengembangan kegiatan MIS dari tahun ke tahun pun relatif sama pula. Guru tidak memiliki kesempatan memverifikasi permasalahan yang dirumuskan TIM RKAM, sehingga sering kali berbagai masalah yang mendesak dan benar-benar harus diselesaikan, tidak terakomodasi. Partisipasi guru dalam pemetaan masalah sangat penting, karena mereka yang merasakan masalah yang sebenarnya berdasar pengalaman sehari hari dalam pelaksanaan tugas. Mereka adalah pelaku utama pembelajaran yang setiap saat berada di madrasah. Tanpa partisipasi guru dalam pemetaan masalah dimungkinkan masalah yang sebenarnya tidak akan terungkap, sehingga berbagai permasalahan tidak dapat diselesaikan.

\section{Partisipasi guru dalam penetapan anggaran}

(Herminingsih, 2009), menemukan bahwa partisipasi pegawai dalam penganggaran berefek terhadap keterlibatannya dalam pelaksanaan program yang berpengaruh terhadap kinerja lembaga. Bahkan Newsrtrom menyebut "participation tends to improve performance and job-satisfaction, has an effect on both satisfaction and productivity, tends to improve motivation, because employees feel more accepted and involved in the situation." Dengan demikian partisipasi guru dalam penganggaran merupakan hal penting agar terbangun kesadaran untuk turut memastikan penganggaran dialokasikan dengan tepat sesuai kebutuhan, dioperasikan sesuai ketentuan, sehingga dapat menjamin ketercapaian tujuan.

Partisipasi guru dalam penetapan anggaran dalam kategori rendah $(69,2 \%)$. Hal tersebut karena pengalokasian anggaran sudah diatur dalam ketetapan anggaran BOS, sehingga tim anggaran cukup mengikuti panduan yang diberikan. Anggaran dibuat dalam bentuk aplikasi online, yang bertujuan memungkinkan terjadinya transparansi dalam pengelolaan keuangan di madrasah. Secara lengkap, tingkat partisipasi guru dalam penganggaran, dapat dilihat di bawah ini.

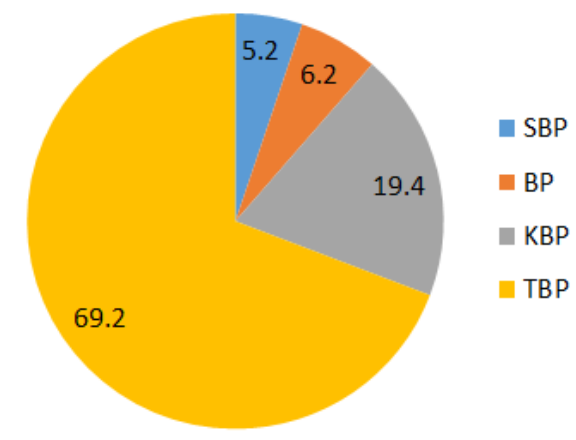

Gambar 6. Partisipasi Guru dalam Penetapan Anggaran

Berdasar uraian di atas dapat ditarik kesimpulan sementara, dalam seluruh aspek RKAM, partisipasi guru sangat memprihatinkan, dalam kategori sangat rendah. Padahal partisipasi guru dalam penetapan rencana kegiatan madrasah merupakan titik awal dalam mewujudkan partisipasi dalam seluruh aspek kegiatan di madrasah. Bahkan Smyle menyebutkan partisipasi guru dalam pengambilan keputusan rencana yang akan dilakukan merupakan salah satu strategi reformasi pendidikan yang paling menjanjikan, 
walaupun dalam kenyataannya kesempatan guru untuk berpartisipasi sangat terbatas (Smylie, 1992).

Partisipasi guru dalam RKAM merupakan langkah strategis dalam mewujudkan keterlibatan guru dalam implementasi RKAM, yang menjembatani pencapaian tujuan madrasah. Oleh karena itu partisipasi guru dalam segenap aspek harus diupayakan secara terus menerus sehingga terbangun budaya berpartisipasi yang mampu melahirkan rasa tanggung jawab terhadap pencapaian tujuan madrasah. Walau dalam kasus berbeda namun masih relevan dengan pentingnya partisipasi guru dalam implementasi program di madrasah, seperti temuan Muthi yang membuktikan terdapatnya hubungan yang positif antara partisipasi guru dalam pengambilan keputusan dengan partisipasi guru dalam implementasi dan pengawasan kinerja di MTs se-KKM MTsN Cimerak-Pangandaran" (Muthi, 2019). Diperkuat Enjang yang membuktikan bahwa pembuatan keputusan kepala madrasah dan partisipasi guru baik secara parsial maupun simultan memiliki pengaruh terhadap implementasi RKAM (Somantri, 2017). Hal tersebut karena guru yang terlibat dalam pekerjaan manajerial akan merasa bertanggung jawab terhadap kemajuan sekolah yang berdampak terhadap peningkatan kinerja akademik siswa. (Hema, 2014). Menyadari pentingnya keterlibatan guru dalam peningkatan kualitas sekolah, Pemerintah Nepal memutuskan untuk mengalihkan kewenangan pengelolaan sekolah kepada warga sekolah (termasuk guru) sebagai langkah reformasi untuk perbaikan sekolah. (Sharma, 2013).

Lebih lanjut, partisipasi guru juga berefek terhadap kepemimpinan sekolah, seperti penelitian Liu dan Yin yang membuktikan bahwa partisipasi guru dalam penetapan rencana dan kegiatan secara signifikan memperkuat kepemimpinan kepala sekolah ketika guru berpartisipasi tinggi dalam pengambilan keputusan sekolah (Liu \& Yin, 2020). Semakin tinggi tingkat partisipasi guru dalam pengambilan keputusan, semakin signifikan munculnya kepercayaan terhadap pimpinan dalam memandu keberhasilan sekolah (Newcombe \& McCormick, 2001). Kepercayaan terhadap pemimpin, mempermudah kepala sekolah menggerakkan segenap unsur dalam mengoperasikan sekolah yang berdampak terhadap efektivitas pencapaian tujuan di sekolah.

Hasil FGD menunjukkan, terdapat beberapa faktor penyebab rendahnya partisipasi guru dalam penetapan RKAM di MIS Kabupaten Karawang. Pertama, Rendahnya pemahaman guru terhadap pentingnya keterlibatannya dalam penyusunan RKAM dikarenakan belum optimalnya sosialisasi RKAM secara menyeluruh terhadap para guru. Kedua, persepsi guru bahwa RKAM merupakan wilayah pimpinan sehingga menyebabkan guru abai atau tidak peduli. Eksklusivitas Tim RKAM diduga turut berpengaruh terhadap pandangan guru bahwa RKAM bukan urusan mereka. Ketiga, belum optimalnya upaya yang dilakukan pihak Kemenag maupun pihak yayasan dalam pemartisipasian guru dalam RKAM.

Sesungguhnya, banyak upaya yang dapat dilakukan untuk meningkatkan partisipasi guru. (Dodd \& Konzal, 2003) merekomendasikan perlunya sekolah/madrasah melakukan kontrak (agreement), membangun "engagement" dengan cara memberi kesempatan seluasnya pada guru untuk terlibat dalam penetapan visi, misi, program serta strategi implementasinya. Selain itu menurut Hulya Pehlivan "Ministry of Education and the administration in schools should organise activities to lead teachers into participating in such events, and thus teachers should be encouraged to join in those activities" (Pehlivan \& Koseoglu, 2013). Dengan demikian, memberi kesempatan kepada guru untuk berpartisipasi seluas luasnya dalam berbagai aspek kehidupan madrasah perlu dilakukan secara terus menerus sehingga terbangun budaya partisipasi di madrasah.

Merujuk pada temuan Sekiguchi yang menyatakan bahwa anggota organisasi yang berstatus sosial tinggi menunjukkan lebih terlibat dalam partisipasi dibandingkan yang berstatus sosial rendah. Tingkat pengetahuan anggota berpengaruh terhadap kesediaan berpartisipasi dalam organisasi (Sekiguchi et al., 2017). Dengan demikian, guna peningkatan partisipasi guru di madrasah, perlu dilakukan melalui penguatan kapasitas guru dalam berpartisipasi dengan cara peningkatan 
pengetahuan dan penyadaran akan pentingnya partisipasi dalam mendukung pencapaian tujuan sekolah/ madrasah.

\section{Faktor Individu yang berpengaruh terhadap partisipasi}

Dalam aktivitas organisasi, partisipasi merupakan gambaran kerajinan kerja anggota organisasi (Senia, 2006). Tingkat partisipasi dipengaruhi: (1) karakteristik personal yang terdiri dari usia, lama kerja, jenis kelamin, dan tingkat pendidikan; (2) karakteristik pekerjaan yang terdiri dari tantangan pekerjaan, konflik peran, dan ambiguitas peran; serta (3) lama bekerja memberikan pengaruh terhadap tingkat partisipasi seseorang (Senia, 2006). Kwakman memberi bukti empiris, bahwa terdapat sejumlah faktor yang mempengaruhi partisipasi, faktor pribadi lebih signifikan dibanding faktor lingkungan kerja, meskipun faktor-faktor tugas dan lingkungan kerja menunjukkan efek, namun jauh lebih kecil daripada efek faktor pribadi (Kwakman, 2013).

Berkaitan dengan hal tersebut, penelitian ini mencoba mengeksplorasi faktor individu yang berpengaruh terhadap partisipasi guru, utamanya terkait dengan faktor usia, masa kerja dan status pegawai. Hal ini penting guna merumuskan rekomendasi dalam upaya peningkatan partisipasi guru dalam RKAM. Tingkat partisipasi ditinjau dari usia, lama kerja dan status pegawai, dapat dilihat pada tabel bawah ini.

Tabel. 1. Partisipasi Guru Dilihat Pengalaman Kerja, Usia dan Status Pegawai

\begin{tabular}{|c|c|c|c|c|c|c|c|c|}
\cline { 2 - 9 } \multicolumn{1}{c|}{} & \multicolumn{3}{c|}{ Pengalaman } & \multicolumn{3}{c|}{ Usia } & \multicolumn{2}{c|}{ Status Pegawai } \\
\cline { 2 - 9 } & $\begin{array}{c}<\mathbf{8} \\
\text { Tahun }\end{array}$ & $\begin{array}{c}\mathbf{9}-\mathbf{1 6} \\
\text { tahun }\end{array}$ & $\begin{array}{c}\mathbf{>} \mathbf{1 7} \\
\text { Tahun }\end{array}$ & $\mathbf{2 9}$ & $\mathbf{3 0 - 3 9}$ & $\mathbf{< 0}$ & $\begin{array}{c}\text { Pegawai } \\
\text { tetap }\end{array}$ & $\begin{array}{c}\text { Pegawai } \\
\text { tidak } \\
\text { Tetap }\end{array}$ \\
\hline SBP & 39.3 & 52.1 & 9.3 & 30.2 & 56.8 & 15.4 & 40.3 & 12.3 \\
\hline BP & 20.2 & 21.4 & 9.3 & 46.3 & 21.2 & 12.3 & 30.2 & 15.4 \\
\hline KBP & 28.2 & 11.2 & 33.1 & 12.4 & 13.2 & 27.1 & 13.3 & 29.7 \\
\hline TBP & 12.3 & 15.3 & 48.3 & 11.1 & 8.8 & 45.2 & 15.2 & 40.6 \\
\hline
\end{tabular}

Keterangan

SPB : Sangat Berpartisipasi

$\boldsymbol{B P}$ : Berpartisipasi

$\boldsymbol{K B P}$ : Kurang Berpartisipasi

TPB : Tidak Berpartisipasi

Berdasar tabel.1, diketahui faktor usia berpengaruh terhadap partisipasi guru dalam penetapan RKAM. Guru berusia antara 30-39 tahun menunjukkan sangat berpartisipasi $(56,8 \%)$, disusul oleh guru yang berusia di bawah 29 tahun $(30,2 \%)$. Guru yang berusia di atas 40 tahun, sebanyak $45 \%$ tidak berpartisipasi. Tidak dapat disangkal bahwa kemampuan kerja seseorang cenderung menurun seiring dengan bertambah usia terutama setelah melewati masa produktif (Cotrim et al., 2019). Setelah ditelusuri ternyata guru yang sangat berpartisipasi berusia relatif muda, yang pada umumnya memiliki kemampuan mengoperasikan IT. Sedangkan guru yang berusia di atas 40 tahun, kurang memiliki kemampuan mengoperasikan IT.
Dengan demikian salah satu kriteria penunjukan guru dalam tim RKAM adalah kemampuan mengoperasikan IT.

Dilihat dari pengalaman kerja, yang menunjukkan sangat berpartisipasi adalah guru dengan masa kerja 9-16 tahun. Hal tersebut relevan dengan tingkat usia mereka antara 3039 tahun. Yang berusia di atas 40 tahun dengan partisipasi yang sangat tinggi adalah para kepala sekolah atau pengurus Yayasan. Temuan ini menunjukkan bahwa karakteristik pribadi yang mencakup usia dan masa kerja berpengaruh terhadap komitmen organisasi. Masa kerja seseorang dalam sebuah organisasi berpengaruh positif terhadap tingkat partisipasi sebagai bentuk komitmen terhadap organisasi (Senia, 2006). 
Diketahui status pegawai guru juga berpengaruh terhadap partisipasi guru dalam penetapan RKAM. Guru yang sangat berpartisi dalam penetapan RKAM sebagian besar $(40,6 \%)$ adalah guru tetap yayasan. Walau terdapat guru honorer yang berpartisipasi, namun hanya sebagian kecil saja. Pada umumnya guru honorer tidak berpartisipasi. Sangat wajar hal tersebut terjadi, karena selain keterbatasan waktu mereka berada di madrasah, juga terdapatnya perasaan bahwa kewajiban guru honorer hanya sebatas mengajar pada jam tertentu. Menurut mereka, kegiatan madrasah secara menyeluruh adalah tanggung jawab guru tetap (Yayasan dan ASN). Hal tersebut berimplikasi terhadap rendahnya partisipasi mereka dalam implementasi kegiatan, yang berdampak terhadap kurang optimalnya dalam pencapaian tujuan madrasah.

Secara diagramatik, partisipasi guru berdasar masa kerja, usia dan status pegawai, dapat dilihat pada grafik di bawah ini.

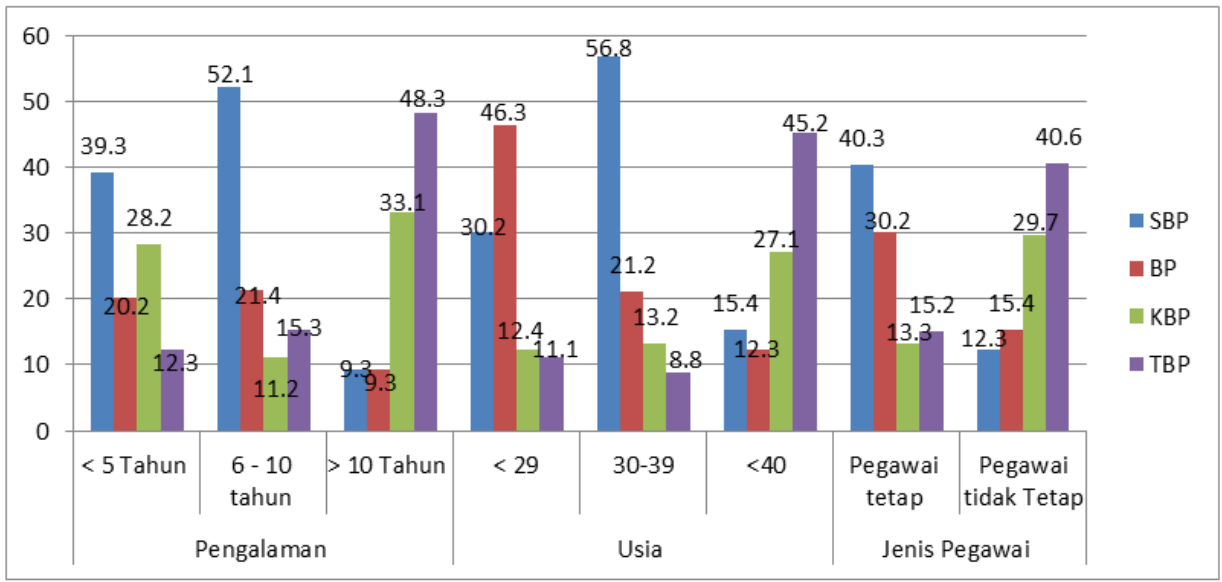

Gambar 7. Partisipasi Guru dalam RKAM berdasarkan Masa Kerja, Usia dan Status Pegawai

Kondisi tersebut sering mempersulit kepala sekolah untuk memperoleh dukungan dalam implementasi rencana dan anggaran yang berdampak terhadap kurang optimalnya pencapaian tujuan pendidikan. Hal tersebut seiring dengan temuan Hema yang membuktikan bahwa partisipasi guru dalam administrasi sekolah dan pengambilan keputusan mampu membentuk komunitas guru, sehingga mempermudah memobilisasinya (Hema, 2014). Guru yang terlibat dalam aktivitas administratif, termasuk di dalamnya dalam penetapan rencana menjadikan mereka merasa menjadi bagian dari organisasi sekolah, sehingga mampu meningkatkan kinerja akademik siswa. Dengan demikian, partisipasi guru dalam perencanaan kegiatan dan anggaran merupakan faktor determinan untuk memperoleh dukungan dalam implementasi rencana kegiatan.

\section{PENUTUP}

Banyak kekurangan dalam penelitian ini semata mata karena berbagai keterbatasan dalam penelitian ini, diantaranya adalah terbatasnya lingkup penelitian yang hanya memfokus pada partisipasi guru MIS, tanpa membedakan status guru. Selain itu waktu maupun wilayah penelitian juga terbatas, dikarenakan terbatasnya kesempatan dalam melalukan penelitian. Penelitian ini merupakan pendahuluan dalam payung penelitian MBS, yang akan dikembangkan terus ke dalam tema tema lainnya.

\section{Kesimpulan}

Pemahaman guru terhadap RKAM baik pada aspek rencana kegiatan, penganggaran dan pengoperasian sistem e-RKAM sangat rendah, yang berimplikasi terhadap tingkat partisipasi dalam penetapan RKAM. Keterbatasan kapasitas dalam berpartisipasi diduga merupakan salah satu faktor yang dominan.

Partisipasi guru dalam RKAM dalam kategori rendah. Hanya Tim RKAM yang beranggotakan kepala sekolah, bendahara, operator dan guru yang membantu pengisian EDM yang menunjukkan sangat berpartisipasi. Sebagian besar guru kurang berpartisipasi, karena mereka terfokus menjalankan peran 
utamanya sebagai pelaksana pembelajaran. Belum optimalnya sosialisasi pemartisipasian serta minimnya kesempatan guru berpartisipasi dalam operasional manjemen madrasah menyebabkan minim atau rendahnya guru partisipasi dalam penetapan RKAM. Kondisi tersebut berefek terhadap rendahnya partisipasi guru dalam implementasi kegiatan di madrasah, yang pada gilirannya tujuan, target dan sasaran tidak tercapai secara optimal.

Faktor usia, masa kerja dan status kepegawaian berpengaruh terhadap tingkat partisipasi guru dalam penetapan RKAM. Guru dengan pengalaman kerja 9-16 tahun dengan rentang usia 30-39 tahun, dan berstatus sebagai guru tetap, menunjukkan lebih berpartisipasi dibanding guru yang berpengalaman di atas 16 tahun dengan usia di atas 40 tahun. Keterbatasan mengoperasikan sistem eanggaran menjadi faktor pemicu atas ketidaksediaan berpartisipasi.

\section{Rekomendasi}

Madrasah, dalam hal ini, kepala sekolah secara terus menerus hendaknya melakukan sosialisasi terhadap guru tentang pentingnya berpartisipasi dalam seluruh aspek manajemen madrasah, terutama dalam penetapan RKAM. Selain itu pemberian kesempatan seluas luasnya kepada seluruh guru untuk berpartisipasi dalam setiap aspek manajemen guna mewujudkan transparansi dan akuntabilitas pengelolaan MIS.

Pemerintah, dalam hal ini Kementerian Agama Pusat Pusat perlu membuat sistem pemartisipasian guru dalam manajemen madrasah yang disosialisasikan dan dimonitor dalam implementasinya. Hal ini penting dalam upaya memandirikan madrasah dan membangun transparansi serta akuntabilitas madrasah sesuai prinsip MBS.

Yayasan tidak terlibat langsung dalam penetapan kegiatan anggaran, namun lebih memosisikan sebagai pembina. Oleh karena itu rangkap status sebagai pengurus yayasan sekaligus sebagai pimpinan madrasah harus ditiadakan.

\section{UCAPAN TERIMAKASIH}

Terima kasih disampaikan kepada responden atas informasi dan pendapat yang diberikan, sehingga penelitian ini memberikan informasi yang sangat penting bagi pengembangan kelembagaan di Madrasah. Selain itu terima kasih kepada UNJ yang telah mendanai penelitian melalui BLU.

\section{DAFTAR PUSTAKA}

Arnstein, S. R. (2007). A Ladder Of Citizen Participation. Journal of the American Institute of Planners, 35(4), 216-224. https://doi.org/https://doi.org/http://dx.do i.org/10.1080/01944366908977225

Cotrim, T. P., Ribeiro, C., Teles, J., Reis, V., Guerreiro, M. J., Janicas, A. S., Candeias, S., \& Costa, M. (2019). Monitoring Work Ability Index During A Two-Year Period Among Portuguese Municipality Workers. International Journal of Environmental Research and Public Health, 16(19), 1-12. https://doi.org/10.3390/ijerph16193674

Davies, B., \& Ellison, L. (2003). The New Strategic Direction and Development of the School. Routledge-Taylor \& Francis Group. https://doi.org/10.4324/9780203984642

Dodd, A. W., \& Konzal, J. L. (2003). How Communities Build Stronger Schools. Palgrave Macmillan Publishing.

Fuad, N. (2015). Manajemen Berbasis Sekolah. UNJ Press.

Griffin, R. W. (2020). Management 5th. Delhi: AITBS Publisher.

Grinshtain, Y., \& Gibton, D. (2017). Responsibility, authority, and accountability in school-based and non school based management: Principals' coping strategies. Journal of Edicational Administration, 56(1).

Hema, G. (2014). Participation O F S Econdary $G$ Rade $T$ Eachers I $N S$ Chool A Dministration $F$ Or Quality. MIER Journal of Educational Studies, Trends \& Practices, 4(2), 272-281.

Herminingsih. (2009). Pengaruh Partisipasi dalam Penganggaran dan Peran Manajerial Keuangan Daerah Terhadap Kinerja Pemerintah: Studi Empiris 
Pemda Demak. USI, Medan.

Kemenang. (2020). Data emis. http://Emispendis.Kemenag.Go.Id/Dashb oard/?Content $=$ data-Statistik\&action= kab\&prov $=32 \& \mathrm{kab}=15$

Kennedy, M., \& Tilly, C. (2019). Field Education and Community-Based Planning in a Worst-Case Scenario. Journal of Planning Education and Research, March. https://doi.org/10.1177/0739456X19847 725

Kerlinger, F. R. F. of B. R. (1996). Foundation of Behavioral Research. Holt, Rinehart \& Winston.

Kwakman, K. (2013). Factors affecting teachers' participation in professional learning activities, Teaching and teacher education.

Liu, S., \& Yin, H. (2020). How ethical leadership influences professional learning communities via teacher obligation and participation in decision making: A moderated-mediation analysis. Educational Management Administration \& Leadership, 1741143220975766.

Maryanti. (2009). Pengaruh Karakteristik TujuanAnggaran Terhadap Perilaku, Sikap dan Kinerja Pemda Provinsi NTT. USU Medan.

Matin. (2013). Dasar-dasar Perencanaan Pendidikan. PT Raja Grafindo Perkasa.

Mbowane, K. C., Villiers, J. J. R. de, \& Braun, M. W. H. (2017). Teacher participation in science fairs as professional development in South Africa. South African Journal of Science, 113, 1-7.

Morman, S., \& Wohlstetter, P. (1994). School Based Manajement : Organizing for High Performance. Jossey Bass Publiser.

Muthi, H. (2019). Pengaruh partisipasi guru dalam pengambilan keputusan dan implementasi pengawas terhadap kinerja guru. Madrascience: Jurnal Pendidikan Islam, Sains, Sosial, Dan Budaya, 1(2), $51-71$.

Ndekha, A., Molgaard, E., P, H., \& Furu, G. W.
P. (2003). Community participation as an interacti $v$ e learning process: experiences from a schistosomiasis control project in. Acta Tropica. 85, 325338.

https://doi.org/https://doi.org/10.1016/S0 001-706X(02)00256-5

Newcombe, G., \& McCormick. (2001). Trust and Teacher Participation in SchoolBased Financial Decision Making. Educational Management \& Administration, 2(92), 181-195. https://doi.org/https://doi.org/10.1177/02 63211x010292004).

Newstrom, J. W. (2015). Organizational Behavior: Human Behavior at Work (fourteenth). McGraw-Hill/Irwin.

Nurhattati. (2015). Manajemen Sekolah. LPP Press Universitas Negeri Jakarta, FIP UNJ.

Nurhattati. (2017). Perbandingan Partisipasi Guru dalam Penggambilan Keputusan di SDN dan SDS: Studi Kasus di SDN Rawamangun13 dengan SD Kinderfield Jakarta Timur.

OERI. (1994). Consumer Guide.

Pehlivan, H., \& Koseoglu, P. (2013). An Analysisi of Teacher Level of Participation in Culture Aktivities. WCES 2013, Procedia Behavioral Science.

Permendiknas. (2007). Standar Pengelolaan Pendidikan oleh Satuan Pendidikan Dasar dan Menengah.

Robbins, S. P., \& Judge, T. A. (2017). Organizational Behavior (Seventeent). Pearson Education.

Rudito, B., \& Budiman, A. (2003). Metoda dan Teknik Pengelolaan Comunity Development. Indonesia Center fo Suistainable Development (ICSD).

Sakaran, U. (2006). Research Method for Business. Salmeba 4.

Sekiguchi, T., Li, J., \& Hosomi, M. (2017). Predicting Job Crafting From the Socially Embedded Perspective: The Interactive Effect of Job Autonomy, Social Skill, and Employee Status. Journal of Applied 
Behavioral Science, 53(4), 470-497. https://doi.org/10.1177/00218863177274 59

Senia, L. (2006). Pengaruh Masa Kerja, Trait Kepribadian, Kepuasan Kerja, Dan Iklim Psikologis Terhadap Komitmen Dosen Pada Universitas Indonesia. Makara Human Behavior Studies in Asia, 10(2), 88.

https://doi.org/10.7454/mssh.v10i2.33

Sevilla, C. (1988). An Introduction to Research Methods.

Sharma. (2013). No Title. https://doi.org/DOI: http://dx.doi.org/10.3126/ jer.v1i0.7954).

Smylie, M. A. (1992). Teacher Participation in School Decision Making: Assessing Willingness to participate' Educational Evaluation and Policy Analysis.

Somantri, E. A. (2017). Pembuatan Keputusan, Partisipasi Guru Dan Implementasi RKM Madrasah Aliyah Swasta." Jurnal Administrasi Pendidikan. Jurnal Administrasi Pendidikan UPI, 24(1), 119-129.

Suharto, E. (1997). Pembangunan Kebijakan
Sosial dan Pekerjaan Sosial: Spektrum pemikiran. LSP-STKS.

Sumaryadi, I. N. (2010). Sosiologi pemerintahan: dari perspektif, pemberdayaan, interaksi, dan sistem kepemimpinan pemerintahan Indonesia. Ghalia Indonesia.

Suryosubroto. (2001). Human dalam Dunia Pendidikan: Suatu Pendekatan Praktis. PT. Mitra Gama Widya.

Tilaar, H. A. R. (2002). Membenah Pendidikan Nasional. Rineka Cipta.

Wandersman, A., \& Florin, P. (2000). Citizen Participation and Community Organizations. Kluwer Academic / Plenum Publishers.

Zheng, K., Hongbiao, Y., \& Shenghua, H. (2019). Teacher participation in schoolbased professional development in China: does it matter for teacher efficacy and teaching strategies? Teachers and Teaching. https://doi.org/: https://doi.org/10.1080/13540602.2019.1 662777 